\title{
MUSIC, IDENTITIES, AND INTERRELIGIOUS RELATIONSHIPS AT THE LINGSAR FESTIVAL IN LOMBOK, INDONESIA
}

\author{
David Harnish \\ Department of Music, University of San Diego, California, USA \\ $<$ dharnish@sandiego.edu $>$
}

\begin{abstract}
When the final procession was readied at the Lingsar temple festival in 1988, I was surprised to see a leader of the Muslim Sasak faction, Suparman, holding hands with the leader of the Hindu Balinese assemblage, Anak Agung Gede Biarsah, at the front of the line of participants. In earlier conversations, they had both expressed interethnic distrust and proclaimed that their group held the inner position while the other was outer and insubstantial to festival events. And yet, there they were walking hand-in-hand and leading the final procession together as if there were no problems whatsoever. What I was witnessing - as I later realized-was the collapse of contestation into interethnic unity, and what produced this unity was the previous days' rites and performing arts, which all worked in various ways to construct a bridge to the ancestors, impose a spiritual order and balance on the proceedings and participants, and form a comprehensive union that gradually became palpable. Ultimately, it is this union of complementary dualities (Sasak/Balinese, human/divine, inside/outside, even traditional/ modern) that generates the fertility that legitimizes the festival. Though many elements have changed since the 1980s, the goal of union has not. Without it, the festival would either discontinue or radically transform.
\end{abstract}

\section{Introduction}

Festivals, particularly those culturally embedded or religious in nature, break the flow of time (see Falassi 1987), allow for special behaviors, and offer possibilities to relive histories and legends/culture heroes, and to reconsider belief, relationships, one's self and community and belonging, and so forth. Sometimes the event or its music compels such actions, or induces unity between dyadic religious groups, as recounted in the quote above. The performing 
arts at the Lingsar festival, an event that likely spans 400 years, structure the event and color nearly every stage and development over the five days of the festival. They offer a promise of transformation and a pathway between human and divine, past and present, and Sasak and Balinese (the two parties sharing Lingsar). No recurring festival (annual or otherwise) is ever exactly the same twice; there are too many agents and variables for close mimicry. There are, of course, templates or maps for how festivals should unfold, and leaders and participants intend to follow them. But, move forward one year and they have changed their perspectives or feelings, new leaders or participants are in place, the weather is different, musicians are sick and can't attend, or some happening - political changes or social tensions - has altered relationships between participants, and suddenly the festival is different. From a hermeneutical or phenomenology perspective, duplication is neither possible nor desirable. At Lingsar and elsewhere, it is individual and collective agency that both sustains and shapes the festival in new ways year-after-year.

I first attended the Lingsar festival, called by the Balinese Pujawali ("Worship Return"), in 1983; after visiting the Lingsar temple and interviewing leaders and participants multiple times over years and attending festivals in 1987 and 1988, I wrote my dissertation (1991). My interlocutors insisted that the "ritual" (or otherwise performed) music and the rites within the festival are "tetap sama" (the same as always) (see Harnish 2005). I believed them. Over decades and after many more encounters witnessing the festival and its participants, it gradually became clear that things sometimes change, that every festival is a renegotiation between the players, their understanding (sometimes new understanding) of the past and with contemporary forces. Most all festivals need to address now - this moment, this year - while still fulfilling historic missions. Compromises are made and certain aspects - rites, music, interpretations, experiences - change. But, some things also stay the same (or nearly so), such as the roles of music and dance, not only as context-sensitive structuring agents but in transforming time, place, and identity and restoring a new unity - again and again. Festivals may be mechanisms for communities to define or redefine themselves and it is the performing arts that articulate that definition. A festival is "an assemblage of texts" (Geertz 1973), and the participating community has the opportunity to tell "a story about itself and for itself” (Sciorra 1995: 65).

This paper is a long-view ethnography of sorts and examines the structuring and transformative powers of music, but also looks at histories of change and at individual actions while focusing on the interface between 
music, musicians, and epiphenomenal connections. The Lingsar temple, its festival and rites, were once a demonstration of the power of the Balinese kings to provide sufficient rainwater, and thus represented noble power and the promise of fertility (see Gerdin 1982 and Harnish 2001 and 2006), themes that have been sustained over time. Today, the festival is more democratic, national, and Muslim and Hindu, consisting of a series of intraand inter-group rites. I strongly feel that leaders and musicians play the most important roles in constructing events, their sequence and their outcomes, and in affecting the environment and everyone within earshot. Music is inescapable at festivals. One can never separate, however, festival from its participants, both past and present. Festivals, both political and spiritual, are public barometers for measuring socio-religious and political change.

\section{Interreligious Relationships at Lingsar}

Lingsar is unique in conjoining some 20,000 Sasak Muslims and Balinese Hindus in time, place and worship. Ideally a festival connects participants to a common origin point in time. That point of time, however, is contentious. Sasak are considered the indigenous population and the Balinese are migrants from neighboring Bali. Balinese came and occupied Lombok, displacing Sasak kingdoms for 150 years (and over 200 years in the west) until Sasak leaders invited the Dutch to intervene, and Dutch forces defeated the Balinese in 1894 and then colonized the island. The many thousands of Balinese remained in Lombok, which they considered their home. The fact that Lombok and Sasak Muslims were ruled by Hindus/non-Muslims is a subtext at the festival and much contemporary life on the island (see Hägerdal 2001). Balinese and Sasak have respective legends. For Balinese, divine forces invited a prince in East Bali to come to Lombok and directly to Lingsar, and to restore righteousness to the island's governance; the legend has rationalized the Balinese occupation and continued presence in Lombok. The Sasak legend of origins is explained in the section below. While each wants to claim the festival (and temple and temple lands) for themselves, the ritual and political reality is that they need each other; and, by the end of each festival, participants transcend division and feel a sense of interreligious unity. The following section will explore further how that happens.

In 1894 - let alone the 1600 s when the temple was reportedly first built - there were not many differences between local Balinese Hindus and Sasak Muslims; "Hinduism" and "Islam" were not politicized and these groups practiced a similar adat (customary ritual practice and law) that connected people to the land, 
their ancestors, and each other. Islamic leaders were different, however, and many Sasak went on the Haj in the late $19^{\text {th }}$ century (and throughout the $20^{\text {th }}$ and $21^{\text {st }}$ centuries), and came back seeking to separate adat from agama (world religion-Islam), to divide society and use Islam to rally against the Hindu Balinese occupiers. During Dutch colonization and early independence years the festival continued with less fanfare. But, for the Balinese, the meaning of the temple changed. The original Pura Lingsar (Lingsar Temple, now called Pura Lingsar Barat - West Lingsar Temple) had been dedicated to celebrating the Balinese victory over Sasak and was largely restricted to families of upper castes only. With the construction of a "new" Pura Lingsar sometime between $1860-70$, gradually all Balinese could enter the gaduh (or gadoh, the upper/inner courtyard) and pray together as a community, although for decades commoners were not welcomed. Elderly commoner Balinese mentioned that in their youth in the 1950 s, they only rarely stepped foot in the gaduh and felt more comfortable worshipping with Sasak farmers. That is not the case today and Balinese of every social level are intricately involved in rites and socializing within the gaduh, which functions to unify Balinese in ritual activities and nurture religious community identity.

Sasak participants attended rites in an adjacent courtyard, the kemaliq, and Balinese joined them for some worship there and also in the many processions over the five festival days. In addition was the culminating rite of the main festival day (full moon of the $6^{\text {th }}$ month in the Balinese calendar, the $7^{\text {th }}$ month of the Sasak calendar), Perang Topat; this involves two sides in outer courtyards hurling topat (rice squares wrapped in banana leaves) at each other for up to 30 minutes. For ten generations, there have been Sasak pamangku (customary priests) officiating at Lingsar. Nearly always, they were subordinate to the Balinese rajas and Krama Pura (temple organization). Indonesian independence provided an opportunity to assert independence from the Balinese and counter-narratives to the Lingsar history and festival meanings.

The 1960s were tumultuous and tension-filled. In 1965-66 came the anti-communist slaughter that killed approximately one million people nationally and tens of thousands locally (see Pepplinkhuizen 1991). Those targeted in Lombok were ChineseIndonesians and Wetu Telu, the Sasak nominal Muslims that had retained adat and working relationships with Balinese; as an agrarian community, many Wetu Telu favored land reform. Survivors flocked to Islam for protection. Those without a "world religion" throughout Indonesia were suspected of being communists and the Wetu Telu faith was not considered 
Islam and thus not acknowledged. They were vulnerable.

Tuan guru, charismatic religious leaders, have had significant political influence since the Balinese period, when they adamantly opposed Balinese rule (see Kingsley 2010 for more on tuan guru). Some tuan guru struggled against the Dutch and the early independence government; through pressure, they impacted all policies enacted on Lombok since independence and many leaders, tuan guru and other haji, were elected or appointed to offices. One district leader in 1968 sent a letter to the Sasak pamangku at Lingsar that stated he could no longer officiate at the festival because he is supposed to be a Muslim and the festival clearly is not Islamic. This set off a firestorm and the Balinese eventually managed to overturn the official's decree; however, the pamangku could only officiate at Lingsar if he did so on cultural grounds, not religious grounds. This decision created a divide between budaya (culture) and agama (religion) that people (mostly Sasak) repeat today this despite some Sasak actively praying to divine ancestors in the kemaliq during the festival. For the Balinese the Lingsar festival is a practice of religion; for the Sasak, it is a practice of culture.

Since the 1960s an increasingly modern, educated, urbanized and Islamized Sasak citizenry have abandoned or denigrated adat, which has resulted in a decrease of Sasak participation at the festival. But, through the agency of Sasak pamangku - from Sanusi (1960s-1993), to Asmin (19932006) and Suparman (2006-present) - the orientation of Sasak participation shifted toward Islam. Prayer periods with clergy at Lingsar were initiated before each festival perhaps just before the 2000s (and the pamangku invites some noted imam) and the Sasak legend of the founding of the Lingsar site began to forcefully assert Lingsar as a major point of origin of Islam, that an evangelist, assisted by God and some assistants, founded the site and water springs. In some recent festivals, two men dressed as Arabs have joined the proceedings, including both processions and prayer periods, upholding the legend's contention that the founders of the temple were Islamic evangelists. The official opening of the Perang Topat, headed by the regional government (the vice governor or governor have spoken every year since 1988), makes it decisively clear that a Sasak (or Javanese-cum-Sasak) founded Lingsar and the water springs, sacrificed himself into the spring for the benefit of all, and that current Sasak citizens are "descendants" of that cultural hero. The government has adopted the Sasak story of Lingsar without knowledge or consideration of other narratives, not only because it makes claims to dominion over Lingsar but is also a point of cultural pride on an island that 
is supposed to be Sasak rather than Balinese. Telle (2014) highlights a similar point of contestation: a failed Balinese attempt to build a large temple and the interreligious friction between Sasak and Balinese in the 21 st century.

The temple and surrounding lands are sites of contention. Within the temple lands are the major water springs for the rice fields throughout West Lombok; some Lingsar water is used to irrigate fields as far away as Central Lombok. Guarded by sacred eels, a sacred pond is located within the kemaliq (also within Pura Lingsar Barat) that people and temple officiants use during purifications. During festivals, officiants, in consultation with subak (rice collectives), determine the flow of water into the fields for the next year. The festival thus regulated irrigation water, and officials still make decisions concerning irrigation throughout most rice fields in the west. At one time, the Balinese raja and festival calendar determined when to plant seedlings and harvest; today, those decisions are made by subak and many have chosen to use fast-growing strains that deviate from the calendar. During Dutch colonization, Balinese acquired leases to the land, which have legally stood up until today. Sasak officials and the festival pamangku have attempted to make a case for Sasak stewardship; the assertive legend and new pre-festival prayers have attracted new attention of governing officials. Pamangku Sanusi managed to wrest control of the kemaliq from the Balinese during his tenure and Pamangku Suparman has registered the kemaliq as a separate site from the pura (temple), while the lands, for now, are still owned by Balinese.

The temple and its festival, while not always considered "sacred" today, are loci of wide-ranging beliefs that primarily fall into a religion category. Reenacting culture, as the Sasak publicly do, rededicate their commitment to ancestors because it was their ancestor, according to the legend, who divinely sacrificed himself (moksa, leaving his spirit at the spot) into the water to create and sustain fertility and abundance. The water is his essence and thus the springs are sacred. The word "kemaliq" refers to a place made sacred and protected by taboos. It is a Wetu Telu term, part of a web of sacred spaces and rites to ancestralize the landscape. To government religious officials, a paradox arises when a kemaliq, a pre-reformed Islamic site under the jurisdiction of adat, is thought to be associated with Islam. Attempts at Islamizing can only progress so far. Balinese legends, on the other hand, hold that it was the deity of the area, Batara Gede Lingsar, who brought them to Lingsar (led initially from Bali by butterflies transformed from falling leaves) and manifested himself through creating the water springs when they arrived, marking the spot as sacred. In modern Balinese Hinduism, 
water is connected to Batara Wisnu (Vishnu), and thus the water connects with Balinese Hinduism in two very significant ways: As an ancestralizing force (and pact with the local divine) and for Hinduizing the festival through the power of one of the trinity of global Hinduism. The temple was so important politically and agriculturally that the raja seized the festival as a state ceremony (Gerdin 1982: 216), perhaps before the 18th century; successive rajas did not relinquish control until 1894.

Further complicating the relationships between Balinese and Sasak are reformist organizations that have intervened in the festival and forced officiants to take heed. Nahdlatul Watan (NW) was established in 1936 by the highly esteemed Tuan Guru Haji Zainuddin Abdul Majid (1904-97), influenced by the rather conservative Naqsybandiyah order of Sufism, which has roots in Lombok since before mid-19th century (see Clegg 2004). The current though outgoing governor, Tuan Guru Bajang, is TGH Majid's grandson. NW and the modernist, "traditionalist" Nahdlatul Ulama (NU) have worked to eradicate Wetu Telu traditions and villages, and the governor forbade Balinese and even traditional Sasak performing arts at state events. Nadhlatul Ulama (NU) and Muhammadiyah are Javaneseoriginated 20th-century reformist organizations that have made inroads into the intellectual class and Javanese bureaucrats (see Harnish 2014). Many officials governing within West Lombok are members of these organizations. On the Balinese side is Parisada Hindu Dharma Indonesia (PHDI), a Hindu reformist organization originating in Bali that went national and gained strength through literati and intellectuals on Lombok attempting to further Hinduize existing rituals and festivals, like Lingsar's. Specifically at Lingsar and other major Balinese temples in Lombok, PHDI has influenced changes in the performing arts, advocating for standard, homogenous music performances (gamelan gong kuna, kidung praise singing, gamelan baleganjur) and religious practice; for instance, through PHDI's influence nearly all Balinese know some sung chants that used to be the domain of high priests (padanda). They want to give direct access to the prime tenets of the religion to all Balinese; in the process, local traditions are discouraged or disallowed. All reformist organizations have sought to cease the heterogeneity that marked the Lingsar festival since its origins.

\section{Rites within the Festival ${ }^{1}$}

Three of the five official days of the festival are active: the first, second and fifth. The other two days are "empty" and allow otherwise busy people to arrive, pray, picnic, and return home,

1 I am not including here the pre-festival rites held on the grounds. For those, see Harnish (2006). 
completing their minimal obligations. I highlight here only a few major events. The first day (one day before the full moon) features an abundance of processions. The day and festival are awakened by a Balinese gamelan gong kuna (large ceremonial gamelan of metallophones, gong-chime, gongs and drums) early in the morning in a pavilion just outside the gaduh (see Figure 1). Musicians and priests state that this performance calls together deity and human worlds. The music floods throughout the temple complex. Within a few hours the Sasak gamelan baris, consisting of gamelan tambur instruments (drum and gong) plus rebab (fiddle), suling (flute), gongs and drums performs on a nearby pavilion. Both music sometimes overlap. The musicians play all day until they join in the processions (Figure 2).

The processions are the major initiating and concluding rites (see Harnish 2018); they are journeys through the appointed path to connected

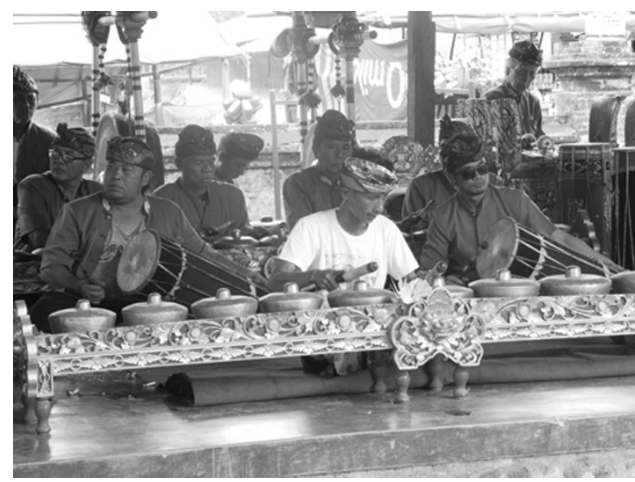

Figure 1. Musicians of a Gamelan Gong Kuna on the Pavilion Outside the Gaduh, 2017. Photo by Author. sacred sites (often involving water). In the early afternoon of the first day of the festival, a large procession generally called Mendak Tirta (Greet Holy Water), is led by a Sasak gamelan ensemble called tambur and followed by Sasak batek baris and sometimes telek dancers (see below). Gamelan tambur - consisting solely of a gong and drum - is associated with the earliest ancestors at Lingsar, public displays of Lingsar's spiritual power (the instruments themselves are sacred) for everyone's benefit, and provides a Sasak claim to ownership (see Figures $3,4)$. The participants, however, are overwhelmingly Balinese, who add three more processional gamelans, either beleganjur (without reong kettlegongs) or gong gilak (with reong). The procession goes eastward to a temple with a sacred water spring; another procession with little fanfare proceeds west to a different water spring and temple. Common priests (pamangku) in each group collect water at the temple

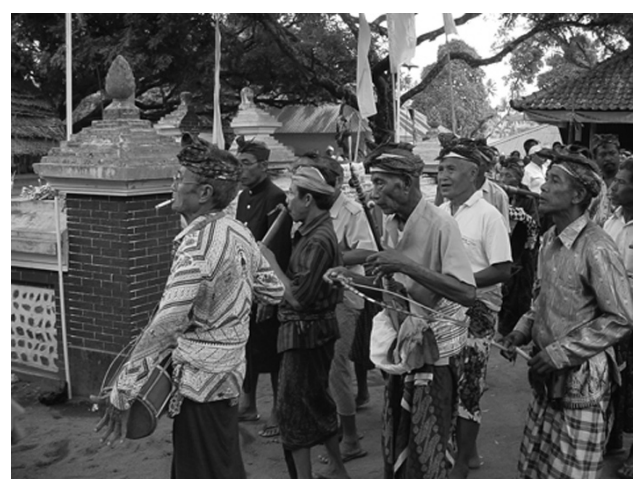

Figure 1. Musicians of Gamelan Baris Circumambulate the Kemaliq, 2017. Photo by Author. 
into two vessels with specific colors, representing the two high deities of Bali (at the western spring) - Batara Gunung Agung (white color, deity of the largest mountain in Bali) and Batara Alit Sakti (red, deified ancestor of Balinese rulers; immaculately conceived, he directed Balinese to Lombok) - and of Lombok (at the eastern spring) - representing Batara Gede Rinjani (black, deity of the high mountain in Lombok) and Batara Gede Lingsar (yellow, the deity at Lingsar). Then these two processions converge on the three-way intersection outside the entrance to the Lingsar temple. Led by Balinese pamangku, the waters and deities are "married" through a prayerful ritual by approximately 1,000 mostly Balinese, thus unifying Bali and Lombok together under Balinese control and confirming the Balinese legend. Long ago many Sasak participated in this procession; today, however, the only Sasak are the gamelan musicians, some dancers

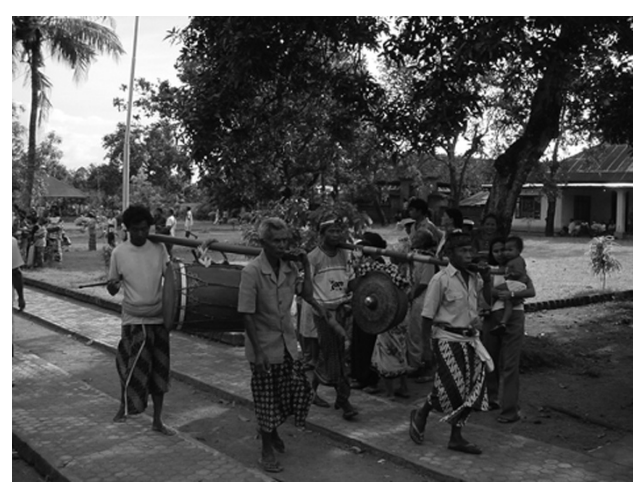

Figure 3. Musicians of the Gamelan Tambur Lead Mendak Tirta, 2001. Photo by Author. for a related performance, and a few officials, because Sasak do not want to be seen supporting the Balinese claim over Lingsar. In addition, one interlocutor suggested that the procession appropriates the gamelan tambur - owned by the land and the original ancestors - under Balinese control. While there was a time when this procession symbolized Balinese dominion of the Sasak and Lombok, ritual life has become politicized over recent decades and Sasak have defied Balinese narratives of the occupation era.

The Sasak Batek Baris (or just Baris) dancers are eight men dressed in Dutch military uniforms and carrying rifles (most of them non-functional), led by a komanden (commandant) carrying a sword and barking orders to the "soldiers" in Sasak with a few Dutch words. The Telek dance involves young women cross-dressed as culture heroes, generally unnamed king, general and

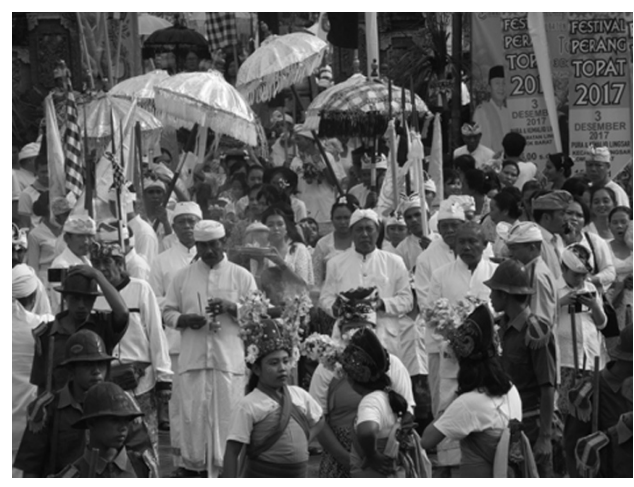

Figure 4. Batek Baris and Telek Dancers Assemble for Mendak Tirta with Balinese Officials, 2017. Photo by Author. 
scout, again related to the coming of the evangelists. Two other women portray batek warriors. ${ }^{2}$ Some have suggested that the dance is a reenactment of a local legend of a princess falling in love with a commoner and that the cross-dressing (women as male heroes) generates fertility, which is one of the primary rationales of the festival. According to most Sasak interlocutors, this platoon symbolizes the security for the leaders of the original Islamic mission from Java, represented by the Telek and Batek dancers, and is a reenactment using the most powerful images of the $20^{\text {th }}$ century: Dutch soldiers with guns. Though the dancers simply walk eastward with the procession, their very presence is protective.

Countering the Balinese procession and prayer unifying Bali and Lombok, an assembly forms at the Sasak pamangku's compound to process to the kemaliq, called Mendak Kebon Odeq (Greet Kebon Odeq). This is when the paired, primary festival offerings, kebon odeq (little garden, male and female), are publicly paraded over about 30 minutes and placed onto the central shrine, alongside numerous dressed stones, in the kemaliq. These offerings consist of fruits, Chinese coins, flowers and seeds and work to unite complimentary duality - king/ queen, male/female, Balinese/Sasak

2 The women are supposed to be unmarried. Some years, two women participate and then usually dress as batek. If there is a third, they will don the king outfit.
- and again make a claim of Sasak ownership (Harnish 2001). Also carried in this procession is the momot, a sealed bottle opened at the end of the festival mysteriously containing liquid, and secondary offerings called pesaji, always made in increments of nine (Figure 5). The procession is again led by gamelan tambur (or gamelan baris), followed by the offerings and then two-three other gamelans. As they arrive to the kemaliq, the congregation holds a prayer period with gamelans performing in front of the primary altar next to the sacred pond. The procession, and perhaps most Lingsar processions, needs to be loud to announce its great significance as participants march through space. Past interviews reveal that the martial, masculine processional music intimidate malevolent spirits and protect participants (Harnish 2006). No Balinese participate in the procession, though a few join in the prayers.

A major procession with both

Balinese and Sasak follows, and

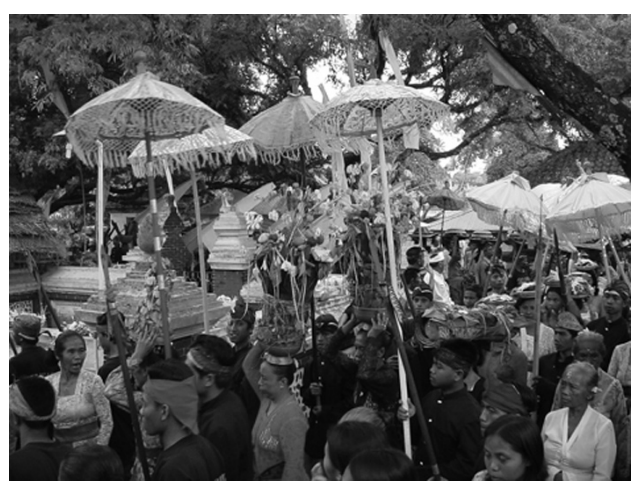

Figure 5. The Two Kebon Odeq (Middle) and Momot (Front) circumambulate the Kemaliq Courtyard, 2001. Photo by Author. 
includes perhaps 2,000 people. A water buffalo is escorted around the exterior of the Pura Lingsar complex three times with Balinese and Sasak processional gamelans leading the way, along with Sasak dancers (Figure 6) and Balinese priests. This rite is believed to offer the buffalo to the deity and it is sacrificed and consumed the following morning and afternoon (usually a second buffalo as well; one for Sasak, one for Balinese). ${ }^{3}$ At the conclusion of this procession, smaller processions form in the gaduh (all Balinese) and kemaliq (mixed, though primarily Sasak), circumambulating the inner altars three times. To some, these circumambulations initiate the bridge to the ancestors and the birth of the festival. ${ }^{4}$ After the procession in

3 At the 2017 festival, three water buffaloes were sacrificed.

4 Many participants see the three main days and opportunities for processions, together equaling nine $(3 \times 3)$, relating to cosmological numerology. The numbers 3 and 9 are ritually important for both Sasak and Balinese. While these three circumambulations initiate the festival, others on the second day sustain it, and those on the last day terminate it, symbolizing the three stages of life.

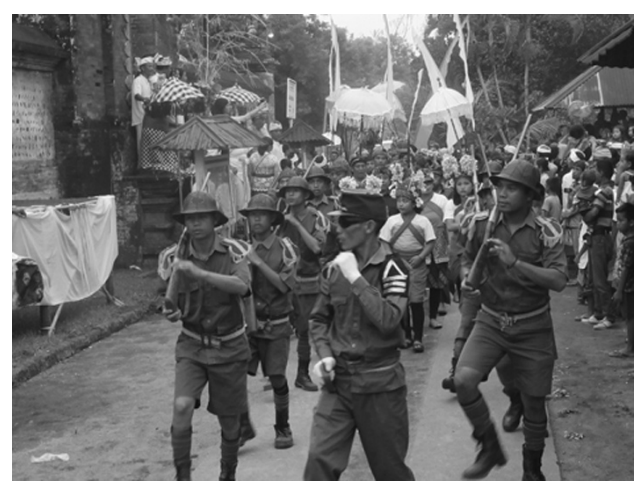

Figure 6. The Batek Baris and Telek Dancers Circumambulate Pura Lingsar, 2017. Photo by Author. the kemaliq, the Batek Baris and Telek dancers sometimes perform for the deity in front of the main altar; if so, the congregants may be asked to sit.

The main day consists of similar rites: Balinese and Sasak gamelan performances throughout much of the day and a second procession from the Sasak pamangku's compound to the kemaliq honoring new pesaji offerings (and a second prayer period within the kemaliq), along with respective feasts (buffalo, vegetables, and rice), a gamelan gong Sasak (a style modeled after early Balinese gamelan gong kebyar) performing on an outside pavilion, and a great deal of activity within the gaduh. Several Balinese gamelans may be playing and a kidung club sets up in the kemaliq for Balinese worshippers (Figure 7). The gaduh is packed with Balinese in the early afternoon preparing for the mass worship ceremony known as Mabakti (to do devotion; sometimes called Panca Sembah, five-times prayer), and high priests (padanda) are conducting their ritual (maweda and mabanten). As people are congregating and in accompaniment to the padandas' rituals, a dance, Rejang Dewa, is performed by eight women dressed in yellow and white. Rejang Dewa (Offering to God) is a relatively new dance created in Bali for use in temples without a rejang (female offering) type of dance (Figure 8). It came to Lombok fully endorsed by PHDI, part of a strategy 
to homogenize ritual arts; it replaced Topeng used during worship, and has been performed annually in the gaduh since 1997 or 1998. In 2017 (and likely in festivals a year or two earlier), another rejang-type dance, Rejang Renteng (featuring mature women) was performed; this dance has been trending at festivals throughout Bali and Lombok in the 2010s. A second (or third) dance, Canang Sari (Essence of Betelnut), begins just outside the gaduh entrance. An offering dance that used to feature five male dancers, today around 20 dancers, including women and children, carry offerings and dance in a long line into the center of the gaduh, then give the offerings to Balinese pamangku, who arrange them in altars (Figure 9). Following these prayers and those in the kemaliq (which includes some Balinese), the governor or vice governor and the district head give speeches recognizing the profound history and nature of the festival and heralding the pluralism and tolerance at the festival

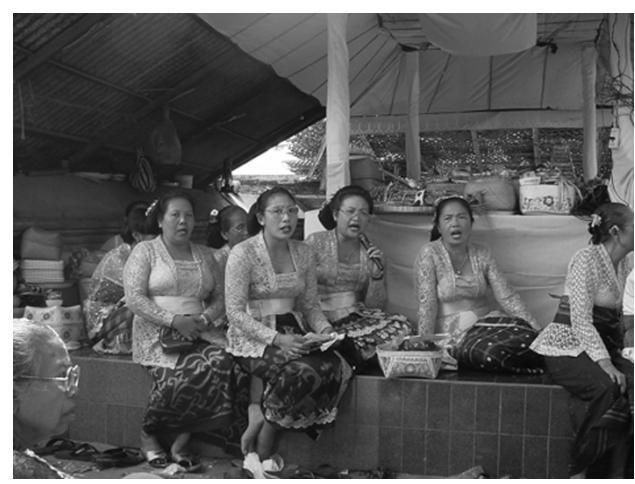

Figure 7. A Kidung Club in the Kemaliq, 2001. Photo by Author while upholding the Sasak version of history. To my knowledge, Governor Tuan Guru Bajang, has, probably on religious grounds as a tuan guru, not attended during his years in office. ${ }^{5}$

The culminating rite is Perang Topat. The accompaniment is usually a kulkul slit-drum struck rapidly, meant to denote action. Hundreds or a thousand or more participants outside the gaduh and kemaliq hurl rice squares (topat) at each other for 15-20 minutes. ${ }^{6}$ The event ends when all the topat have been hurled, then most participants go home; for many - such as government dignitaries, tourists, orthodox Muslims, and visitors from from other islands, including Bali - this is the last event and they do not return. Farmers

5 I attended these speeches, held outside the temple, for the first time in 2017. Previously I wanted to remain in the courtyards as activities are ongoing during this formal, officious ceremony. I was surprised at how political the talks were, denying any Balinese authority and sometimes ignoring them even within the context of the pluralist narrative.

6 Sometimes some Sasak youth are nakal (naughty) and throw rotten eggs or stones. I have been hit over the years with just about everything, even when I am outside the kemaliq and technically on the Sasak side.

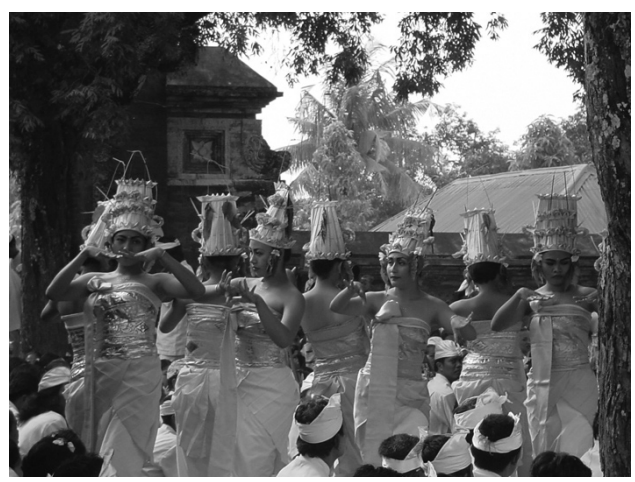

Figure 8. Rejang Dewa Performed in the Gaduh, 2001. Photo by Author. 
collect and place the topat in their rice fields or trees; after being thrown, they are believed to be blessed and to promote fertility. More performing arts disconnected to any rites may be performed on this and/or the previous evening.

The last festival day begins, like the other main days, with gamelan gong kuna, which serves as a soundtrack for the entire event. A final procession advances from the Sasak priest's compound to the kemaliq with gamelans, dancers, and new offerings, then another prayer period follows in both gaduh (all Balinese) and kemaliq (mixed). The prayers, particularly in the kemaliq, ask the deity(ies) to return to the ancestral world.

The final event is a huge procession of the remaining 5,000 or so participants moving out from the Pura Lingsar temple to another temple area to the west, the same temple visiting by a Balinese entourage on the opening day. This is when Sasak and Balinese

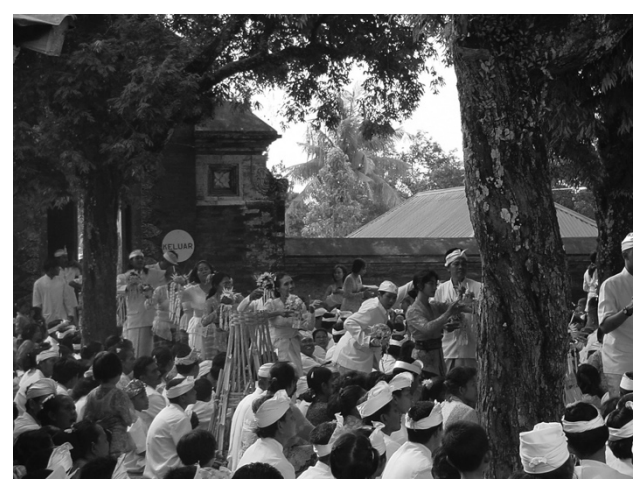

Figure 9. Canang Sari Performed in the Gaduh, 2001. Photo by Author. leaders may hold hands as they walk, symbolizing the reunification of their groups. Processional gamelans (including the Sasak gamelan tambur, which again leads), wooden doublereed players (Balinese who perform instrumental versions of sacred poetry as individual rites), some dancers, temple officials, priests, and individuals and families (representing their communities or villages or just themselves) are involved, and special volunteers carry most of the offerings, including the kebon odeq and momot. While participants from the gaduh pray within the temple upon arrival, those from the kemaliq stop at a river beside the temple to pray, then the Sasak pamangku breaks open the kebon odeq and tens of people clamor to grab the ingredients as they are thrown in the river to go to the sea. Then he unwraps the momot, a bottle that was sealed empty with prescribed leaves and thread at the beginning of the festival. The liquid that mysteriously appears within is considered bestowed directly by the deity, and it is handed out to participants who drink, wash or collect it in their own bottles. It is said to promote purity, health, and fertility, and it is yet another water element. The amount of liquid is considered directly proportional to the level of the coming rainfall for the rainy season, so all hope for an abundant amount. The momot opening concludes the festival. 


\section{Music within the Festival}

The festival serves myriad purposes and ideally has myriad outcomes. The most important of the former are reunifying Balinese and Sasak, transforming time and space and communing with (and receiving blessings from) the divine or ancestors; the most important of the latter are enhanced fertility, health, and abundant rainfall. Unifications of various sorts are goals, because it is within complementary duality that fertility, the union of male and female, results. This is one reason why union between Balinese and Sasak is a festival objective despite all of the rhetorical contestation preceding and even during the event. Of course, there is also extensive social bonding throughout the event - as Balinese mix with Balinese they rarely see, and Sasak with Sasak, and Sasak and Balinese - and during the festival the crucial plans for water distribution to subak for the next year are negotiated.

Music and other performing arts drive the festival from its initiation to its conclusion. The arts are vehicles for enacting myth and worship, and for self and community identification. Music, in particular, structures the rites, serves as the soundtrack as well as soundscape, and sometimes, instead of accompanying behavior, constitutes a rite unto itself. This festival, like others, is context-sensitive and sometimes context-specific, and nurtures spiritual experiences within rites with intermingling and intertextuality of actions, emblems and icons. A foundation of the festival is to make the past present via associated music tradition (for example, the gamelan tambur and the Sasak ancestors and Lingsar founding, and gamelan gong kuna with Balinese ancestors and cosmology), and legends reenact and represent the temple's founding through dance and music, while newer and older idioms of Islam and Hinduism abound.

Even though the festival has changed since 1983 - altered schedules for certain rites, new Islamic prayer periods (and stopping before the early evening Magrib), greater Sasak determination over the kemaliq, and numerous renovations paid by the government (to increase tourist marketability) or by reformist organizations (to make the physical appearance more standardized) - and the socio-religious orientation of the participants has largely changed (Sasak and Balinese more Muslim and Hindu, respectively), the functions of the arts have not markedly changed. Their responsibilities have been maintained despite many changes within the performing arts. One long-held tradition (for hundreds of years, perhaps), preret double-reed playing to accompany all kebon odeq activities, ended in the mid-1990s; Balinese Topeng Pajegan or Topeng Panca (masked theatre abstractly 
featuring a story about Lingsar's founding performed by soloist or small ensemble), was replaced by Rejang Dewa a few years later and today we have the added Rejang Renteng; Canang Sari changed from a solemn offering dance featuring only men to a lighter event welcoming women and children; Gandrung, a flirtatious Sasak dance with fertility elements (women picking men out of the audience for spontaneous dance) disappeared though sometimes returns without those elements; kidung, Hindu praise singing usually featuring women's groups, was a Balinese addition to the kemaliq by the late 1990s; gendang beleq, the Sasak modernist and loudest processional ensemble featuring elaborate choreography, was added in the late 1990s (2-4 groups commonly perform); and gamelan tawaq-tawaq, another Sasak processional ensemble, has made regular appearances in one or more of the processions for about 20 years (Figure 10). These changes are

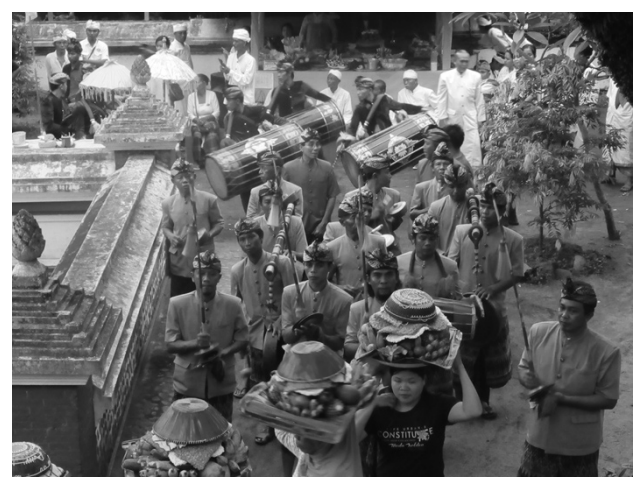

Figure 10. Gamelan Tawaq-Tawaq Performs in the Kemaliq with Gendang Beleq Positioned Behind, 2017. Photo by Author inspired by sociopolitical and religious changes.

One prime example of an inspired change is the preret solo and duo double-reed tradition. Before 1993, the Sasak pamangku invited preret musicians to accompany the making and procession of the kebon odeq offerings and the rites of the pamangku each year. I knew several players over the decades but I was especially acquainted with Amaq Sari and Amaq Salih, who were nearly 60 when I first talked with them in 1987. Both had performed at the festival since before they were married. Performance accompanied the lives of the kebon odeq, from before their creation to their termination. According to interlocutors including Pamangku Sanusi, the kebon odeq could not be made without preret music. The repertoire consisted of instrumental versions of sacred Sasak poetry (badede). Though usually performed solo, when Amaq Sari and Amaq Salih played together, the melodies would be staggered; one would play a line, reach a tone and sustain it, and the other would play the same phrase a second or so later. Pamangku Sanusi mentioned that the music rose like incense smoke to call and escort ancestral deities to the festival, that the music served as a bridge. The instrument's very loud sound and its repertoire, however, were prominently featured and solidly Wetu Telu; the tradition, though normally played solo, marked other pre-Islamic 
ceremonies within kemaliq elsewhere in Lombok. The instrument and repertoire stand for "Wetu Telu." While Sasak interlocutors were unable to explain the preret players' absence, Balinese counterparts were quick to identify Islamization as the reason. The tradition did not fit the movement toward Islam; arts reflecting Wetu Telu ancestor beliefs refute the profile of participants and festival as modern and Islamic. The Sasak pamangku after Sanusi have not invited the musicians to play, though sometimes the Balinese Krama Pura organization invites one of them to play for cleansing ceremonies in the kemaliq. I was at first surprised to meet Amaq Sari in the kemaliq in 2001 playing for the Balinese cleansing ritual. One Balinese interlocutor mentioned that Amaq Sari was strongly associated with Lingsar performing an art that sacralizes the environment and communicates with the deities of Lombok (see Figure 11). They were happy to invite him and I believe that Sari's performance assists

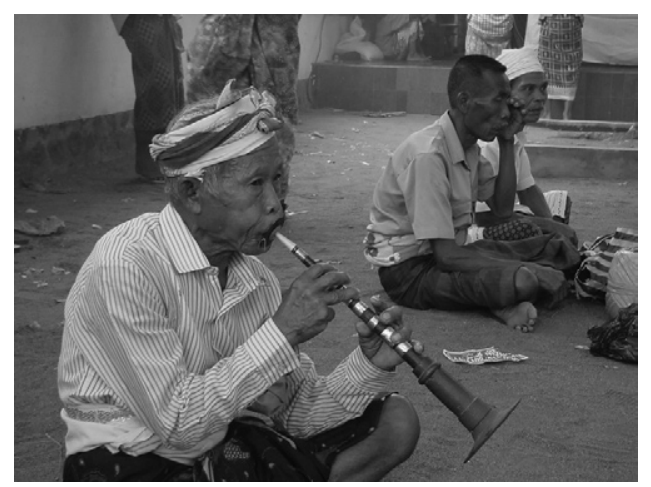

Figure 11. Amaq Sari Plays Preret in the Kemaliq for Balinese Cleansing Ritual, 2001. Photo by Author. the Balinese camp's appropriation of early sacred Sasak arts (along with gamelan tambur in the opening procession) to create their own bridge to local deities.

The Sasak gamelan gendang beleq was added shortly after the divorce of preret from kebon odeq. Though the ensemble performs during processions (and sometimes while seated) and its sound is now crucial for a complete festival experience, it does not play in integral ritual role. Like nearly all early ensemble traditions, gendang beleq was a Wetu Telu ensemble in decline after the 1960s. In the 1980s-90s, the provincial Arts Office made gendang beleq a special project. Officials first decontextualized and secularized the ensemble, then provided grants, materials, and expertise to aestheticize the music (speeding it up and adding more dynamics) and appearance (new choreography and outfits) (Harnish 2007). Through this process, gendang beleq exploded in popularity and soon clubs were invited to play at Lingsar. The ensemble, now considered "Sasak" and no longer "Wetu Telu," inserts a more secular and modernist Sasak cultural aesthetic and expression. Gendang beleq is more dynamic and louder than any other ensemble and 2-4 clubs typically play each year, sometimes overwhelming the soundscape and all other ensembles (see Figure 12). Gendang beleq's addition, and preret's deletion, marks 
the Sasak trend toward "culture" and away from "religion." In the meantime, gamelan tawaq-tawaq, another Sasak processional ensemble (featuring cymbals on tasseled lances) has become a festival mainstay and places more Sasak cultural adat on display.

Balinese Krama Pura officials, with PHDI reformist organization encouragement, now invite a kidung club or two to the festival each year to sing (in unison primarily) the long, unadorned melodic lines of the praise poetry. The (usually only) women singers perform in the kemaliq for most rites there that involve Balinese, but particularly on the main day of the festival when they accompany the lengthy rituals of a padanda high priest seated on a pavilion. Kidung is performed throughout Hindu Bali and is iconic for "Balinese temple festival," though it was only first included at the Lingsar festival in the 1990s. Positioned in the kemaliq, the presence of kidung furthers Balinese

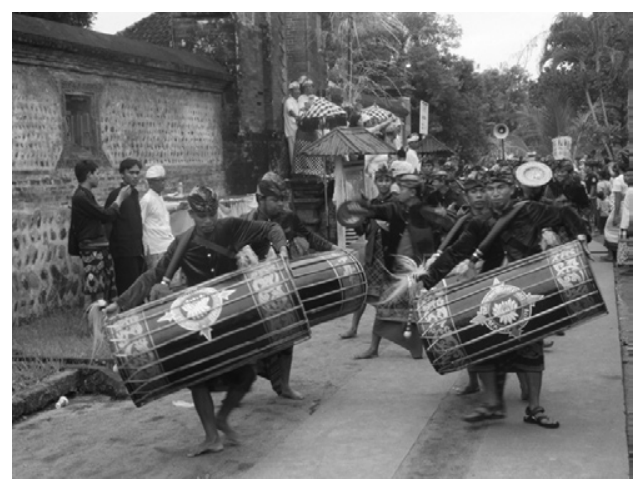

Figure 12. A Gendang Beleq ensemble Circumambulates Pura Lingsar, 2017. Photo by Author. standing there and even Hinduizes the space. The other Balinese additions since the 1980s are Rejang Dewa, the choreographed sacred dance from Bali that PHDI managed to add to festival programs throughout most major temples in Bali, and Rejang Renteng, featuring older women and enjoying even more visibility. ${ }^{7}$ The additions of kidung, Rejang Dewa, and now Rejang Renteng are temporally marked. They occur at specific moments: kidung in the kemaliq for Balinese rites there to coincide with the initial padanda's rituals of purification and offering, and Rejang Dewa and Rejang Renteng in the gaduh, again coinciding with padanda rites (two padanda officiate in the gaduh; one in the kemaliq). These arts assert a modernist, pan-Balinese religious identity and bring much more female energy into performance but divert from the local expression and closer relationship with Sasak in earlier festival life. Table 1 indicates the respective Sasak and Balinese performing arts at Lingsar and their approximate time of introduction to the festival: "Traditional" (likely 19th century or earlier), ">1930" (two gamelans that emerged in the 1930s), and "> 1990" (though newly introduced, arts that now largely characterize the festival).

7 I suspect that Rejang Renteng will supplant Rejang Dewa in coming years because it is more popular and its inclusion makes Rejang Dewa redundant. 
Table 1. Balinese and Sasak Performing Arts at Lingsar

\begin{tabular}{lll}
\hline \multicolumn{1}{c}{ Balinese Arts } & \multicolumn{1}{c}{ Sasak Arts } \\
\hline Traditional & Gamelan Gong Kuna & Gamelan Tambur \\
& Gamelan Gong Gilak & Gamelan Baris \\
& Gamelan Baleganjur & Preret (discontinued) \\
& Canang Sari dance & Batek Baris dance (discontinued) \\
& Topeng dance (discontinued) & Telek dance \\
& & Gandrung dance (largerly discontinued) \\
$>1930$ & Gamelan Gong Kebyar & Gamelan Gong Sasak \\
& Kidung praise singing & Gamelan Gendang Beleq \\
& Rejang Dewa dance & Gamelan Tawaq-tawaq \\
& Rejang Renteng dance (2010s) & \\
\hline
\end{tabular}

\section{Reflections}

The Sasak and Balinese changes in the festival program are parallel to changes in Muslim and Hindu religious identities in Lombok, and these identities have been influenced by largely shaped by reformist organizations and the increasing trend of religiosity over the last 30-40 years (see Harnish 2014). The Balinese and Sasak at Lingsar have negotiated these forces and made decisions that impacted music and musicians at the festival. Sometimes, in the case of Balinese topeng dancers and Sasak preret players, participation has ended; other times, arts new to the festival appear, perhaps to appeal to a new and modernizing society. Though I have been sometimes dismayed with the absence of earlier traditions (that were supposed to be "tetap sama," never changing), Balinese and Sasak agents have been shaping the festival in accordance with contemporary sociopolitical realities.

Despite the changes, some "traditions" remain. The Balinese gamelan gong kuna retains its function of calling human and deities together and announcing the festival while on a pavilion right outside the gaduh. The music is an index of "ceremony" and is necessary to sacralize significant sites, such as temples. The gong kuna does not perform for any specific ritual; it is a rite itself and the prime soundscape for the festival. The music elements - cycling parts, smaller cycles within larger cycles, interlocking parts - usher forth potential spiritual experience and bonding, transforming time, space and the mental state of participants, particularly among the Balinese.

The Sasak gamelan tambur maintains its position as the eldest of traditions, linked to the land and earliest ancestors. It performs during Sasak and mixed processions, and for 
the opening Mendak Tirta procession, when it clears the path of malevolent forces, protects participants, and helps to unify the worlds of Bali and Lombok. The Batek Baris and Telek dances have also retained their narrative functions in reenacting part of the Sasak legends.

The trend has been for Balinese performing arts to be more Hindu and for Sasak performing arts to be more "cultural." I feel that the Sasak pamangku have strategized very well, adding Islamic elements (prayers and themes within legends), omitting items more recognizably Wetu Telu (like preret), and sustaining Sasak participation and even Wetu Telu beliefs regarding ancestors, fertility and rainwater while blunting bans from religious leaders. Balinese officials have gradually allowed programming to become a more standardized Hindu festival, and both Hindu and Islamic reformist forces have succeeded in further dividing the groups, making the ultimate interreligious union more complicated and difficult. But, this union still occurs by the end of the festival. Sasak interlocutors state off-and-on throughout the festival that they enjoy hearing gamelan gong kuna and other Balinese arts; Balinese interlocutors always enjoy Sasak arts. The performing arts flood the environs and, in my opinion, work their magic throughout the festival: cosmological statements via gamelan gong kuna, ancestral indices via gamelan tambur, narratives reenacted in Batek Baris, Telek, Canang Sari, and Rejang Dewa dances, and the intermingling of priests, rites, prayers, actions, and Perang Topat construct a union that at the end of the festival is palpable.

The Lingsar festival is a stabilizing mechanism that remains essential in Lombok to reunite Balinese and Sasak (temporarily), invoke the divine, fertility and rainwater, and to establishing agreements surrounding irrigation water for the next year. In this modern and more fractured world, the festival may be an indispensable way of knowing (or re-knowing) the other.[]

\section{References}

Clegg, Kendra. 2004. "Ampenan: Constructions of Nationalism, Ethnicity and Identity in Lombok." PhD dissertation, Deakin University.

Falassi, Alessandro. 1987. "Festival: Definition and Morphology.” In Time out of Time: Essays on the Festival, edited by Alessandro Falassi, 1-10. Albuquerque: University of New Mexico Press.

Geertz, Clifford. 1973. "Person, Time, and Conduct in Bali.” In The Interpretation of Cultures, 360-411. New York: Basic Books, Inc.

Gerdin, Ingela. 1982. The Unknown Balinese: Land, Labour and Inequality in Lombok. Goteborg: ACTA Universitatis Gothoburgensis. 
Hägerdal, Hans. 2001. Hindu Rulers, Muslim Subjects: Lombok and Bali in the Seventeenth and Eighteenth Centuries. Thailand: Hans Hägerdal.

Harnish, David. 2018. "The Lives of Processions in Bali and Lombok, Indonesia." In Public Festivities, edited by Jack Santino. University of Utah Press.

. 2016. "Revising and Revisiting the Ancestors: Performing Arts, Interethnic Union and Balancing the 'Tradition' and 'Modern' at the Lingsar Festival in Lombok, Indonesia. In Religious Festivals in Contemporary Indonesia, edited by Patrick Alcedo. Manila: Ateneo Press.

. 2014. "Balinese and Sasak Religious Trajectories in Lombok: Interactions, Tensions, and Arts at the Lingsar Temple Festival." In Between Harmony and Discrimination: Negotiating Religious Identities within Majority-Minority in Bali and Lombok, edited by Brigitta Hauser-Schäublin and David Harnish, 61-85. Leiden: Brill Press.

- 2007. “'Digging' and 'Upgrading': Government Efforts to 'Develop' Music and Dance in Lombok." Asian Music 38 (1): 61-87.

. 2006. Bridges to the Ancestors: Music, Myth, and Cultural Politics at an Indonesian Festival. University of Hawai'i Press.

. 2005. "New Lines, Shifting Identities: Interpreting Change at the Lingsar Festival in Lombok, Indonesia." Ethnomusicology 49 (1): 1-24.

. 2001. "'Like King and Queen, Like Balinese and Sasak': Musical Narratives at the Lingsar Festival." Ethnologies 23 (1): 63-87.

. 1991. "Music at the Lingsar Temple Festival: The Encapsulation of Meaning in the Balinese/Sasak Interface in Lombok, Indonesia." $\mathrm{PhD}$ dissertation, University of California, Los Angeles

Kingsley, Jeremy. 2010. “Tuan Guru, Community, and Conflict in Lombok, Indonesia.” PhD dissertation, University of Melbourne

Pepplinkhuizen, Coen. 1991. "Religion: Visions of Duality and Balance.” In East of Bali: From Lombok to Timor, edited by K. Muller, 36-42. Singapore: Periplus Editions, Inc.

Sciorra, Joseph. 1995. "Religious Processions in Italian Williamsburg," The Drama Review 29 (3): 65-81.

Telle, Kari. 2014. "Changing Spiritual Landscapes and Religious Politics on Lombok.” In Between Harmony and Discrimination: Negotiating Religious Identities within Majority-Minority Relationships in Bali and Lombok, edited by Brigitta HauserSchäublin and David Harnish, 35-61. Leiden: Brill Press. 